\title{
Peningkatan Keterampilan Menulis Melalui Media Foto untuk Siswa Kelas V SDN Ngepeh Kecamatan Saradan Kabupaten Madiun
}

\author{
Noffi Irma Yunita ${ }^{1 *}$, Fida chasanatun $^{2}$, Iva Yuni Listiani ${ }^{3}$ \\ ${ }^{123}$ Program Studi Pendidikan Guru Sekolah Dasar, Universitas PGRI Madiun \\ *Alamat email koresponden: noffiyunita1@gmail.com
}

\begin{abstract}
Abstrak
Penelitian ini bertujuan untuk meningkatkan keterampilan menulis siswa kelas V SDN Ngepeh Kecamaatan Saradan, Kabupaten Madiun dalam menulis surat undangan dengan menggunakan foto.Metode penelitian ini menggunakan pendekatan deskriptif kualitatif. Jenis penelitian ini adalah Penelitian Tindakan Kelas (PTK) dengan pengumpulan data melalui observasi, wawancara dan dokumentasi. Teknik analisis data menggunakan model analisis data triangulasi, dan dalam kegiatan analisis dan kegiatan pengumpulan data menggunakan siklus. Berdasarkan hasil penelitian PTK adalah hasil siklus I keterampilan menulis siswa menunjukkan penguasaan subjek penelitian yaitu 59,2\%. Pada siklus II hasil menunjukkan bahwa penguasaan keterampilan menulis siswa mencapai 83,2\%, hasil peningkatan keterampilan menulis siklus I ke siklus II sebanyak 24\%. Peningkatan kemampuan menulis surat undangan hingga ketepatan viabilitas surat yang sesuai. foto, elemen elemen kelengkapan surat, ketelitian kata sopan, ketepatan kalimat, dan penggunaan ejaan dan tata bahasa alat tulis yang tepat. Kesimpulan dari penelitian menunjukkan bahwa media foto dapat meningkatkan kemampuan menulis surat undangan siswa kelas SDN Ngepeh Kabupaten Saradan Madiun pada tahun akademik 2015/2016.
\end{abstract}

Kata kunci: Media Foto, Keterampilan Menulis

\section{Improving Writing Skills through Photo Media for Grade V Students of Ngepeh Elementary School, Saradan District, Madiun Regency}

\author{
Noffi Irma Yunita $^{1^{*}}$,Fida chasanatun ${ }^{2}$, Iva Yuni Listiani ${ }^{3}$ \\ ${ }^{123}$ Primary School Teacher Education Study Program, Universitas PGRI Madiun \\ * Correspondent's email address: noffiyunital@gmail.com
}

\begin{abstract}
This study aims to improve the writing skills of students of class V SDN Ngepeh Kecamaatan Saradan, Madiun district in writing a letter of invitation by using this foto.This research metode using qualitative descriptive approach. This type of research is the Classroom Action Research (PTK) with data collection through observation, interviews and documentation. Data analysis technique uses triangulation data analysis models, and in the activities of analysis and data collection activities using cycles.Based on results of the study of in class action is the result of the cycle I of writing skills students demonstrate mastery of the subject of research that is $59.2 \%$. In the cycle II results show that mastery of writing skills students reached $83.2 \%$, yield increase writing skills cycle I to the cycle II as much as a $24 \%$ increase in the ability to write a letter of invitation to the viability accuracy of the letter corresponding photos, completeness elements section of the letter, polite word accuracy, the accuracy of the sentence, and the use of spelling and grammar proper stationery. Conclusions from the study indicate that the photo media can improve writing skills invitation letter grade students of SDN Ngepeh Saradan Madiun at the academic year 2015/2016.
\end{abstract}

Keywords : Photo Media, Writing Skills 


\section{PENDAHULUAN}

Pembelajaran Bahasa Indonesia SD mencakup komponen kemampuan berbahasa dan kemampuan bersastra meliputi empat aspek yaitu menyimak, berbicara, membaca dan menulis. Menurut Zulela (2013:4) "Tujuan yang diharapkan dalam pembelajaran bahasa Indonesia adalah peserta didik dapat berkomunikasi secara efektif dan efisien sesuai dengan etika yang berlaku, baik secara lisan maupun tulisan". Dalam pembelajaran Bahasa Indonesia menulis merupakan salah satu bagian terpenting dalam kehidupan sehari-hari yang dituangkan dalam bentuk tulisan. Menurut Susanto (2014:249) menyebutkan "Menulis pada dasarnya adalah kegiatan seseorang menempatkan sesuatu pada sebuah dimensi ruang yang masih kosong, setelah itu hasilnya yang berbentuk tulisan dapat dibaca dan dipahami isinya".

\section{Pembelajaran Bahasa Indonesia} khususnya pada keterampilan menulis masih kurang efektif dan media pembelajaran yang digunakan guru belum memadai dalam penerapanya. Problem pengajaran Bahasa Indonesia bagi guruguru pendidikan dasar dan menengah, peserta didik terlalu banyak menjelaskan sesuatu dan tidak banyak memberikan latihan yang cukup kepada siswa untuk memberikan kembali apa yang telah dijelaskan oleh guru. Sebagaimana dikatakan Slamet (2014:26) problem pengajaran Bahasa Indonesia "Siswa lebih banyak disuapi dengan keterangan guru, tidak diusahkan agar mereka sendiri yang lebih aktif. Hal ini ditunjukkan pada waktu pembelajaran berlangsung siswa banyak yang berbicara sendiri dan kurang memperhatikan materi. Media yang digunakan juga kurang sesuai karakteristik siswa yang menimbulkan siswa malas mengikuti pelajaran. Jadi, siswa lebih banyak disuapi dengan keterangan guru dan tidak diusahakan agar mereka sendiri yang lebih aktif.

Dari hasil pengamatan, pembelajaran keterampilan menulis pada pembelajaran Bahasa Indonesia di SDN Ngepeh kecamatan Saradan Kabupaten Madiun Tahun Pelajaran 2015/2016 khususnya kelas $\mathrm{V}$ kurang memberikan kesempatan kepada siswa untuk menuangkan ide maupun gagasan melalui tulisan serta masih mengabaikan pemanfaatan media dalam proses pembelajaran. Sehingga menyebabkan siswa kesulitan menyampaikan gagasan secara tertulis pada kegiatan pembelajaran menulis. Hal ini dapat diketahui dari hasil wawancara dengan guru kelas $\mathrm{V}$ rata-rata nilai keterampilan menulis surat masih rendah pelajaran Bahasa Indonesia dari jumlah siswa kelas V sebanyak 31 dan yang belum mencapai KKM $(\geq 70)$. Dengan hal ini harapan untuk berhasil mencapai keterampilan menulis masih kurang, pada umumnya dikatakan siswa berhasil mencapai sama atau lebih dari 70 . Dengan demikian siswa masih kesulitan menungkan ide ataupun gagasan yang dicurahkan melalui tulisan berdasarkan pengalamannya, serta masih bingung kepada siapa yang akan ditujukkan dan apa yang akan ditulis.

Dari permasalahan di atas, media foto/gambar bisa dimanfaatkan guru sebagai alat penunjang pembelajaran Bahasa Indonesia pada keterampilan menulis yang efektif, yang dapat melibatkan siswa secara aktif dalam proses pembelajaran, sehingga siswa tertarik dan termotivasi untuk mengikuti kegiatan pembelajaran. 
Anitah (2008:8) mengatakan bahwa "Melalui gambar dapat diterjemahkan ideide abstrak dalam bentuk yang lebih realistis". Artinya media foto/gambar menjadi cara untuk mempermudah menuangkan ide-ide dalam bentuk tulisan. Sehingga dengan memanfaatkan foto/gambar dapat menjadi solusi membantu guru dalam mencapai tujuan pembelajaran menulis. Menurut Rohani (2014:76) gambar dapat membantu guru dalam mencapai tujuan instruktusional "Karena gambar, pengalaman dan pengertian peserta didik menjadi lebih luas, lebih jelas dan tidak mudah dilupakan, serta lebih kongkrit dalam ingatan dan asosiasi peserta didik". Sehingga media gambar dalam proses menulis mempermudah menyampaian dan penjelasan mengenai informasi, pesan, ide dan gagasan dengan tanpa banyak menggunakan bahasa-bahasa verbal, tetapi dapat lebih memberi kesan kepada siswa. Menurut Arsyad (2011:113) “Tujuan utama menampilkan berbagai jenis gambar ini adalah untuk memvisualisasikan konsep yang ingin disampaikan kepada siswa". Visualisasi dalam bentuk gambar yang siswa peroleh dari sumber dan konsep ilmu pengetahuan untuk mempermudah dalam memahami materi pembelajaran sehingga menarik belajar siswa. Berdasarkan hal tersebut maka akan dilakukan penelitian tindakan kelas yang berjudul "Peningkatan Keterampilan Menulis melalui Media Foto untuk Siswa Kelas V SDN Ngepeh Kecamatan Saradan Kabupaten Madiun Tahun Pelajaran 2015/2016".

\section{METODE PENELITIAN}

Jenis penelitian ini adalah penelitian tindakan kelas sehingga peneliti akan melakukan tindakan yang memefokuskan pada aktivitas guru dan siswa serta peningkatakan keterampilan menulis. Subjek penelitian ini adalah siswa kelas V SD Ngepeh Kecamatan Saradan Kabupaten Madiun tahun pelajaran 2015/2016, yang berjumlah 31 siswa yang terdiri atas 12 siswa perempuan dan 19 siswa laki-laki, guru kelas $\mathrm{V}$, dan peneliti dengan mata pelajaran Bahasa Indonesia materi pokok "Membuat surat undangan". Alasan memilih kelas V sebagai subjek penelitian karena kelas tersebut bermasalah dalam mengikuti pembelajaran menulis surat, siswa kurang memperhatikan pembelajaran sehingga kemampuan menulis surat rendah, terbukti nilai ratarata kelas 68 di bawah $\mathrm{KKM} \geq 70$ yang telah ditetapkan sekolah.

Penelitian tindakan kelas ini dilaksanakan dalam dua siklus. Setiap siklusnya diselesaikan dalam 1 kali pertemuan ( 2 x 35 menit). Setiap siklus terdiri dari empat tahapan yaitu perencanaan, pelaksanaan, observasi dan refleksi (Arikunto, 2006:16).Teknik pengambilan data dalam penelitian ini adalah, observasi, wawancara dan dokumentasi. Teknik analisis data yang dilakukan peneliti dalam Penelitian Tindakan Kelas ini yaitu triangulasi (Triangulation). Arikunto (2014: 128) berpendapat bahwa, "triangulasi merupakan proses memastikan sesuatu (getting a 'fix') dari berbagai sudut pandang". Triangulasi menggunakan berbagai sumber data untuk meningkatkan kualitas penilaian terhadap hasil belajar

\section{HASIL DAN PEMBAHASAN}

Penelitian dilakukan dengan cara melihat dokumentasi sekolah dan didapat bahwa jumlah siswa kelas V SDN Ngepeh Kecamatan Saradan Kabupaten Madiun 
adalah 31 siswa. Proses pembelajaran yang digunakan selama ini sebgaian besar dengan meotde ceramah, penugasan dan tanya jawab.

Tahapan penelitian ini dilakukan dengan 2 siklus. Setiap siklus meliputi tahapan perencanaan, tindakan, pengamatan dan refleksi. Menindak lanjuti pada kondisi awal dalam pembelajaran menulis siswa kelas $\mathrm{V}$ yang masih rendah, maka peneliti mengadakan tindakan lanjutan pada siklus I peningkatan keterampilan menulis melalui media foto yang alur kegiatan sebagai berikut :

\section{Siklus I}

1) Tahap Perencanaan

Peneliti bersama guru menyampaikan materi yang dipilih, guru bersama peneliti merancang skenario pembelajaran bahasa Indonesia dengan materi menulis memulai kegiatannya dengan membuat silabus dan RPP, menyiapkan instrumen, mensimulasikan RPP dengan guru kelas.

2) Pelaksanaan

Tahap pelaksanaan ini guru memberi salam pembuka, guru menjelaskan tujuan pembelajaran yang akan dilaksanakan dengan memberikan apersepsi, mengaitkan materi dengan pengetahuan siswa saat ini. Kegiatan Inti, guru menjelaskan kepada siswa materi tentang ciri-ciri bahasa dan bagian bagian surat, siswa mendengarkan dan memperhatikan guru menjelaskan materi. Kegiatan selanjutnya guru menunjukan kepada siswa contoh surat, siswa mengamati contoh surat kemudian guru memberikan arahan dan bersama siswa mengidentifikasi ciri dan bagian surat tersebut, siswa untuk mempersiapkan media foto yang telah dibawa, guru memberi kesempatan untuk bertanya tentang materi yang belum paham guru membagikan LKS tentang membuat surat undangan, siswa mengerjakan dengan bantuan melalui foto dan bantuan dari guru waktu yang diberikan guru untuk mengerjakan tulisanya kurang 25 menit. Setelah selesai guru memberikan kesempatan kepada siswa untuk membacakan hasil menulisnya secara bergiliran. Penutup, guru bersama siswa membuat kesimpulan, tahap selanjutnya guru memberikan salam dan penutup,

3) Observasi

Dari hasil Siklus I menunjukkan pembelajaran sudah berjalan dengan baik akan tetapi saat mengerjakan LKS masih terdapat nilai siswa yang belum mencapai KKM. Hasil nilai LKS yang diperoleh siswa pada siklus I sebagaiman telah tercantum pada tabel 1 . 
Tabel 1. Hasil nilai LKS Siklus I dengan

$\mathrm{KKM} \geq 70$.

\begin{tabular}{|c|c|c|c|c|}
\hline \multirow{2}{*}{ No } & \multirow{2}{*}{ Nama } & \multicolumn{3}{|c|}{ Aspek penila } \\
\hline & & $\mathbf{A}$ & B & $\mathbf{C}$ \\
\hline 1. & $\mathrm{~S}$ & 1 & 3 & 1 \\
\hline 2. & AT & 3 & 4 & 4 \\
\hline 3. & $\mathrm{AU}$ & 3 & 4 & 4 \\
\hline 4. & $\mathrm{CE}$ & 4 & 5 & 4 \\
\hline 5. & RE & 2 & 4 & 3 \\
\hline \multicolumn{4}{|c|}{ Siswa tidak tuntas $K K M \geq 70$} & \\
\hline \multicolumn{5}{|c|}{ Keterangan } \\
\hline A & \multicolumn{4}{|c|}{ : Ketepatan isi surat ( skor 5) } \\
\hline $\mathrm{B}$ & \multicolumn{4}{|c|}{ : Kelengkapan unsur surat ( skor 5) } \\
\hline $\mathrm{C}$ & \multicolumn{4}{|c|}{ : Ketepatan kata ( skor 5) } \\
\hline $\mathrm{D}$ & \multicolumn{4}{|c|}{ : Ketepatan kalimat (skor 5) } \\
\hline $\mathrm{E}$ & \multicolumn{4}{|c|}{ : Ejaan dan tata tulis ( skor 5) } \\
\hline 4) & efleksi & & & \\
\hline
\end{tabular}

tindakan siklus I ke siklus II yang menjadi rekomendasi adalah dari siklus I pelaksanaan tindakannya media foto yang dibawa bebas sesuai keinginan siswa sedangkan pada tindakan siklus II pelaksanaan tindakannya media foto yang dibawa berukuran sama dan berwarna kemudian ditukar dengan teman yang lain agar kegiatan menulis siswa lebih bervariatif, sehingga akan berpengaruh pada hasil peningkatan keterampilan menulis pada siklus II.

\section{Siklus II}

\section{1) Tahap Perencanaan}

Peneliti bersama guru menyampaikan materi yang dipilih, guru bersama peneliti merancang skenario pembelajaran bahasa Indonesia dengan materi menulis memulai kegiatannya dengan membuat silabuas dan RPP, menyiapkan instrumen, mensimulasikan RPP dengan guru kelas.
Skor maksimal

(25)

Tidak tuntas

Tuntas

Tidak Tuntas

Tuntas

Tidak tuntas

2

\section{2) Pelaksanaan}

Hal-hal yang dilakukan pada tahap ini yaitu,Kegiatan Inti, pada tahap ini kemudian guru menjelaskan kepada siswa materi tentang ciri-ciri bahasa dan bagian bagian surat, guru menunjukan kepada siswa contoh surat, siswa mengamati contoh surat kemudian guru memberikan arahan dan siswa mengidentifikasi ciri dan bagian surat tersebut dengan semangat siswa menyimak dan melihat contoh surat undangan yang ditunjukkan guru. Guru kemudian meminta siswa untuk mempersiapkan media foto guru memberi kesempatan untuk bertanya dalam kegiatan tanya jawab. Guru membagikan LKS, Siswa mengerjakan dengan bantuan melalui foto waktu yang diberikan guru untuk mengerjakan tulisanya kurang 25 menit, guru memberikan kesempatan kepada siswa untuk membacakan hasil menulisnya secara bergiliran, guru bersama siswa membahas tugas menulis yang telah dikerjakan, dalam hasil penulisanya terlihat lengkap dalam menyebutkan bagian-bagian surat dan lebih teliti dan memperhatikan ejaan dan tata tulisnya. Sebagai bentuk apresiasi terhadap hasil karya siswa guru meminta untuk hasil menulisnya di pajang 
di papan kreatif. Penutup, guru bersama siswa membuat kesimpulan, dan selanjutnya guru memberikan salam dan penutup.

\section{3) Observasi}

Berdasarkan dibawah ini, bahwa hasil belajar siswa dalam menulis surat undangan pribadi melalui media foto pada siklus II sudah baik. Siswa yang mencapai ketuntasan belajar sebanyak 4 siswa, dari jumlah subjek penelitian kelima siswa tersebut secara rata-rata yang mencapai ketuntasan 83,2 \%, hal ini sudah memenuhi standar ketuntasan belajar siswa yang digunakan oleh sekolah SDN Ngepeh $\geq 70$ dengan skor penelitian siswa AT = 96, $\mathrm{AU}=88, \mathrm{CE}=84, \mathrm{RE}=80$. Hasil belajar pada siklus II menunjukkan adanya peningkatan dari siklus I. Dari uraian di atas, dapat disimpulkan bahwa peningkatan hasil belajar pada siklus II baik secara individu dan klasikal telah memenuhi standar ketuntasan belajar.

Tabel 2. Hasil Nilai LKS Siklus II dengan $\mathrm{KKM} \geq 70$.

\begin{tabular}{|c|c|c|c|c|c|c|c|c|c|}
\hline \multirow{2}{*}{ No } & & \multirow{2}{*}{ Nama } & \multicolumn{5}{|c|}{ Aspek penilaian } & \multirow{2}{*}{$\begin{array}{c}\text { Skor maksimal } \\
(25)\end{array}$} & \multirow{2}{*}{ Kategori nilai } \\
\hline & & & $\mathbf{A}$ & B & $\mathbf{C}$ & D & $\mathbf{E}$ & & \\
\hline 1. & $\mathrm{~S}$ & & 3 & 5 & 4 & 3 & 3 & $\frac{17}{25} \times 100=68$ & Tidak Tuntas \\
\hline 2. & AT & & 4 & 5 & 5 & 5 & 4 & $\frac{23}{25} \times 100=96$ & Tuntas \\
\hline 3. & $\mathrm{AU}$ & & 4 & 5 & 5 & 5 & 3 & $\frac{23}{25} \times 100=88$ & Tuntas \\
\hline 4. & $\mathrm{CE}$ & & 5 & 5 & 4 & 4 & 3 & $\frac{21}{25} \times 100=84$ & Tuntas \\
\hline 5. & $\mathrm{RE}$ & & 4 & 5 & 3 & 4 & 4 & $\frac{20}{25} \times 100=80$ & Tuntas \\
\hline
\end{tabular}

\begin{tabular}{l}
\hline Siswa tuntas KKM $\geq 70$ \\
\hline Siswa tidak tuntas KKM $\geq 70$ \\
\hline
\end{tabular}

\section{4) Refleksi}

Berdasarkan hasil tes dan nontes siswa dalam pembelajaran menulis surat undangan pribadi secara keseluruhan menunjukkan bahwa siswa menyukai pembelajaran menulis melalui media foto siswa juga sudah mampu menyebutkan 6 unsur bagian surat secara lengkap sedikit kurang teliti dalam ketepatan ejaan tata tulis, secara keseluruhan siswa sudah menunjukkan hasil yang baik. Pembelajaran melalui media foto ini membantu siswa dalam menulis karena dapat mempermudah kepada siapa surat akan dikirimkan dan menungkan ide dan gagasan pada bagian isi. Dari hasil tersebut proses pembelajaran menulis surat undangan yang dilaksanakan oleh siswa pada siklus II telah berhasil, maka tidak perlu dilakukan pelaksanaan siklus berikutnya.

Aktivitas guru selama proses pembelajaran pada siklus I dan siklus II yang dapat dilihat dari aktivitas siklus I rencana pelaksanaan pembelajaran terdapat 4 aspek penilian aktivitas guru yang belum runtut sesuai skenario pembelajaran, penguasaan kelas dan melebihi alokasi waktu yang telah direncakaan dalam proses pembelajaran. Sedangkan pada siklus II pelaksanaan pembelajaran sudah berjalan dengan baik dari 15 aspek penilaiaan aktivitas guru di dalam kelas, runtut dan 
alokasi waktu sudah sesuai dengan rencana pelaksanaan pembelajaran.

Pelaksanaan pembelajaraan pada aktivitas siswa dilihat selama proses pembelajaran berlangsung dan untuk hasil kegiatan menulis melalui media foto ini peningkatan perolehan nilai yang diperoleh siswa pada pelaksanaan siklus I dan siklus II. Berikut hasil prosentase nilai dari subjek penelitian .

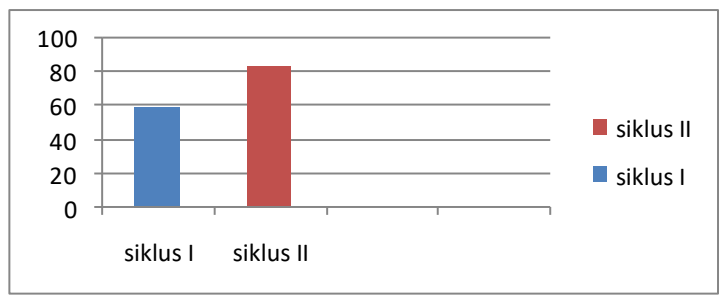

Gambar 1. Diagram Hasil Menulis Siswa Siklus I dan II.

\section{Peningkatan keterampilan menulis melalui media foto untuk kelas $V$.}

Setelah pelaksanaan penelitian hasil peningkatan keterampilan menulis melalui media foto untuk siswa kelas $\mathrm{V}$ pada materi pembelajaran menulis surat undangan, kemampuan menulis siswa mengalami peningkatan. Berdasarkan hasil tes siklus I yang diperoleh dari kelima siswa tersebut terdapat 2 siswa yang tuntas berinisil $\mathrm{AT}=76, \mathrm{CE}=72$ dari hasil kegiatan menulis surat undangan. Nilai siswa yang belum mencapai $\geq 70$ sebanyak 3 siswa belum tuntas mencapai KKM kemampuan menulis. Namun dari kegiatan pembelajaran tersebut sudah mengalami peningkatan meskipun belum seluruhnya tercapai. Sehingga pada siklus II hasil tes yang diperoleh dapat lebih baik dan mengalami peningkatan. Dapat terbukti dari ke-5 subjek penelitian tersebut pada siklus II siswa memperoleh nilai mencapai KKM dengan siswa yang berinisial AT = $76, \mathrm{AU}=76, \mathrm{CE}=84$ dan $\mathrm{RE}=84$ ratarata nilai tersebut sudah tuntas yaitu mencapai indikator keberhasilan $\geq 70$. Jika melihat indikator keberhasilan maka ketuntasan dari ke 5 siswa sudah meningkat meskipun masih terdapat 1 siswa yang belum tercapai yaitu siswa $\mathrm{S}$ karena melihat beberapa faktor mempengaruhi hal tersebut yang dapat dilihat selama proses pembelajaran dari siklus I dan siklus II yaitu melihat dari karakter diri siswa sendiri dan kebiasaan di dalam proses pembelajaran kurang percaya diri, malu dan tergesa-gesa mengumpulkan LKS tanpa mengecek kembali hasil menulisnya, secara keseluruhan tindakan penelitian pada siklus II peningkatan dan keberhasilan siswa meningkat.

Berdasarkan hasil pelaksanaan tindakan awal, siklus I maupun siklus II yang mengalami peningkatan dalam pembelajaran keterampilan menulis surat undangan, maka dapat disimpulkan bahwa penggunaan media foto dapat meningkatkan keterampilan menulis pada Siswa kelas V SDN Ngepeh Kecamatan Saradan Kabupaten Madiun tahun ajaran 2015/2016.

Kelebihan peningkatan keterampilan menulis melalui media foto untuk siswa. Variatif. Penggunaan media ini dapat divariasikan asalkan sesuai dengan materi yang akan diajarkan sehingga membantu siswa memahami materi menulis surat undangan. Siswa selama proses pembelajaran memperhatikan ketika guru menjelaskan materi, siswa sudah mempersiapkan buku pelajaran di atas bangku, terlihat fokus pada pembelajaran dan mencatat materi yang telah diberikan selama pembelajaran suasana kelas yang kondusif. Menyenangkan. Siswa yang senang menulis dengan media foto mempermudah menulis bagian isi. Hasil observasi aktivitas siswa selama proses 
pembelajaran siswa senang membawa foto terlihat semua siswa membawa foto, menunjukkan foto yang dibawa kepada teman-temannya, membaca LKS yang telah diberikan dan segera menulis sehingga dari aktivitas siswa tersebut mempermudah menulis bagian isi. Memotivasi siswa berfikir kritis. Siswa lebih semangat dan memotivasi siswa menghargai hasil menulisnya. Penggunaan media ini seperti metode demonstrasi, sehingga siswa yang lain diberikan kesempatan untuk memberikan pendapat dan menilai hasil karya orang lain. Dengan adanya kesempatan memberikan pendapat, siswa dilatih pula untuk bersikap kritis, melatih keberanian siswa dalam berpendapat, dan membangun sikap aktif dalam pembelajaran.Ssiswa berani untuk membacakan hasil menulisnya dengan suara lantang dan hasilnya dipajang dipapan kreatif.

Kekurangan Media Foto Pada Keterampilan Menulis Siswa

Siswa malu tidak berani maju kedepan membacakan hasil tulisannya. Dalam kegiatan pembelajaran siswa malu dan tidak berani maju kedepan maka akan berpengaruh pada kegiatan pembelajaran dan materi yang diserap, namun dari kekurangan tersebut dari siswa sudah berani maju membacakan hasil menulisnya di depan kelas.

Adapun kekurangan hasil temuan dari menganalisis masalah yang ada dalam proses pengajaran tersebut, maka kekurangan yang ada di SDN Ngepeh tersebut antara lain siswa masih belum paham apa yang akan ditulis dan cara mengirimkan surat berdasarkan foto, hasil observasi selama proses pembelajaran terlihat dikarenakan ada beberapa faktor yang mempengaruhi yaitu dari karakter diri siswa yang memang memerlukan bimbingan yang lebih.

\section{KESIMPULAN DAN SARAN}

Berdasarkan paparan hasil penelitian tindakan kelas diatas, dapat disimpulkan bahwa pembelajaran keterampilan menulis melalui media foto untuk siswa kelas V SDN Ngepeh meningkat.Hasil penelitian dari tindakan kelas ini adalah pada siklus I hasil keterampilan menulis siswa menunjukkan ketuntasan yaitu 59,2\%. Pada siklus II menunjukkan bahawa ketuntasan hasil keterampilan menulis siswa mencapai $83,2 \%$. Peningkatan hasil keterampilan menulis siklus I ke siklus II sebanyak 24\%. Kemampuan keterampilan menulis siswa menjadi meningkat meliputi peningkatan kemampuan dalam menulis surat undangan dengan aspek kemampuan ketepatan isi surat sesuai dengan foto, kelengkapan unsur-unsur bagian surat, ketepatan kata yang sopan, ketepatan kalimat, dan penggunaan ejaan dan tata tulis yang tepat. Selain itu peningkatan terhadap aktivitas guru dalam melaksanakan pembelajaran keterampilan menulis dengan media foto, peningkatan tersebut meliputi melaksanakan proses pembelajaran secara runtut sesuai skenario pembelajaran, membimbing siswa dalam menulis surat, memberikan respon secara positif, melakukan refleksi untuk mengidentifikasi kekekurangan/kesulitan siswa dalam menulis surat undangan dan memberikan pemantapan pemahaman langkah-langkah dalam menulis dengan memperhatikan indikator dalam menulis surat undangan.

Penelitian tindakan kelas yang dilakukan ini tentu terdapat kekurangan dan kelebihan. Peneliti memberikan saran 
kepada guru, siswa dan peneliti lain berdasarkan hasil yang telah dijabarkan. Sehingga dapat digunakan sebagai sumber referensi dan pengembangan bagi penelitian selanjutnya. Saran tersebut antara lain.

Guru. Sebagai bahan masukan bagi guru untuk memilih strategi pembelajaran yang tepat dalam mengajar Bahasa Indonesia, salah satunya adalah dengan menggunakan media foto. Guru diharapkan selalu memberi bimbingan dan pengarahan kepada siswa, khususnya kepada siswa yang hasil belajar belum tuntas dan siswa yang kurang aktif di kelas. Guru diharapkan mampu menciptakan suasana pembelajaran yang bermakna dan menyenangkan serta membangun asumsi positif dalam pembelajaran Bahasa Indonesia dengan memanfaatkan media gambar/foto dengan lebih inovatif dan kreatif.

Siswa. Siswa diharapkan dapat lebih aktif dan interaktif dalam mengikuti pelajaran Bahasa Indonesia setelah menggunakan media foto sehingga, dapat meningkatkan keterampilan menulis dalam berbagai materi khususnya menulis. Selain itu siswa diharapkan menghindari asumsi bahwa menulis itu sulit, dan harus membangun asumsi bahwa menulis yang menarik dan menyenangkan serta dengan penggunaan media foto ini mempermudah siswa untuk menuangkan ide dan gagasannya dalam bentuk tulisan.

Peneliti lain. Penelitian tindakan kelas ini diharapkan dapat menjadi kajian awal bagi penelitian serupa. Peneliti lain dapat mengembangkan penggunaan media foto dalam penelitian ini dan melakukan perbandingan dengan pendekatan maupun media pembelajaran yang lebih bervariatif sehingga dapat memodifikasi media foto ini sesuai dengan inovasi kreatifitas dan kondisi penelitia

\section{DAFTAR PUSTAKA}

Anitah, S. (2008). Media Pembelajaran. Surakarta:LPP UNS dan UNS Press.

Arikunto, S., dkk. (2006). Penelitian Tindakan Kelas. Jakarta: PT. Bumi Angkasa.

Arikunto, S., dkk. (2014). Penelitian Tindakan Kelas. Jakarta: PT Bumi Aksara

Arsyad, A. (2011). Media Pembelajaran. Jakarta:PT Rajagrafindo Persada.

Rohani, S. (2014). Media Instruksional Edukatif. Jakarta: Rineka Cipta.

Slamet. (2014). Problematika Berbahasa Indonesia dan Pembelajarannya. Yogjakarta: Graha Ilmu.

Susanto, A. (2014). Teori Belajar dan Pembelajaran di Sekolah Dasar. Jakarta: Kencana.

Zulela, M. (2013). Pembelajaran Bahasa Indonesia. Bandung: PT Remaja Rosdakarya. 